\title{
Corela
}

Cognition, représentation, langage

17-1 | 2019

Vol. $17, \mathrm{n}^{\circ} 1$

\section{Copular sentences and Binding Theory : the case of French and Principle C}

\section{Valérie Amary}

\section{OpenEdition}

\section{Journals}

Édition électronique

URL : http://journals.openedition.org/corela/8146

DOI : $10.4000 /$ corela.8146

ISSN : $1638-573 \mathrm{X}$

\section{Éditeur}

Cercle linguistique du Centre et de l'Ouest - CerLICO

Référence électronique

Valérie Amary, «Copular sentences and Binding Theory : the case of French and Principle C », Corela [En ligne], 17-1 | 2019, mis en ligne le 24 juin 2019, consulté le 27 juin 2019. URL : http:// journals.openedition.org/corela/8146 ; DOI : 10.4000/corela.8146

Ce document a été généré automatiquement le 27 juin 2019.

\section{(c) (i) (2)(2)}

Corela - cognition, représentation, langage est mis à disposition selon les termes de la licence Creative Commons Attribution - Pas d'Utilisation Commerciale - Partage dans les Mêmes Conditions 4.0 International. 


\title{
Copular sentences and Binding Theory : the case of French and Principle $\mathrm{C}^{\mathbf{1}}$
}

\author{
Valérie Amary
}

\section{Introduction}

1 It is a well-known fact since Chomsky's Pisa Lecture that the referential status of DPs constrains their distribution. Despite the fact that these constraints are being dealt with by other mechanisms in the current Minimalist Program, they can be usefully appraised from the perspective of Governement and Binding Theory (Chomsky, 1981) in which they were initially formulated. How theses constraints are expressed in copular sentences is the topic of this article. The objective is to show that copular sentences are indeed subject to such mechanisms of Principle C of Binding Theory, a constraint on referential expressions. This is against the received wisdom since Fiengo \& May (1994), according to which Principle $C$ is said not to apply to copular sentences. The reason for this view might be that the studies were based on English, which is the impetus for looking here at another language, namely French. Sentences in (1) show that the post-copula constituent cannot refer to the subject of the sentence :

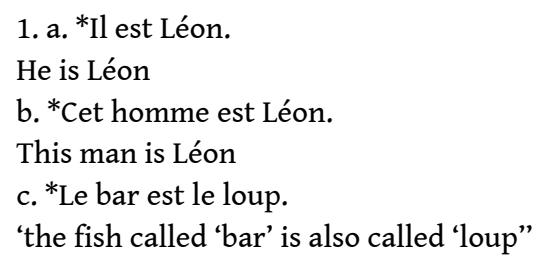

2 The two terms surrounding the verb est co-refer in a c-command structure ${ }^{2}$ : they bear the same reference which yields ill-formed sentences. In fact, this is completely predicted by Principle C: Léon and le loup, being referential expressions, may not be bound by the subject. So, Principle $C$ could apply to copular sentences and the following English copular sentences could be seen as counter-examples that one should be able to explain : 
2. a. He is John

b. This man is John.

c. Cicero is Tullius.

3 The analysis is organized as follows. In section 2, a general overview of Binding Principles is exposed and, then, the problem of English copular sentences with regards to Principle $C$ is discussed. Section 3 shows that French copular sentences do not have the same behaviour as their English counterparts, for non-predicational sentences with the verb etre alone are banned for the $3^{\text {rd }}$ person subjects. Principle $C$ seems responsible for this impossibility. Section 4 makes the assumption that the two XPs bear the same referential index in be-sentences, by definition, and certainly as soon as they get inserted in the derivation. Going further, we assume, following Bowers (1993), that copular sentences are derived from a Small clause structure containing a predicate head $\left[_{\text {Pred" }}\left[\right.\right.$ spec] $\left[_{\text {Préd }}\right.$ Pred [ complement]]. Hence, in XP est XP sentences, we find a Ø Pred head, while in c'est-sentences (XP c'est XP) the Pred head is the demonstrative and yields a surface structure Topic c'est Focus, just as it is proposed by Heycock \& Kroch $(1997,1999)$ for English equative sentences. Principle C applies to the structure XP est XP but not to equatives. Section 5 addresses some remaining issues, which need further development.

\section{Binding Theory and copular sentences}

4 The Binding Theory has been the focus of much research for years : first presented in the Government and Binding Theory in Chomsky $(1981,1986)$ as a core module of this theory, its status and its role in the most recent developments of the generative theory (cf. the Minimalist Program, Chomsky, 1995) appear less clear. Nevertheless, whatever the theoretical frameworks we consider and the status given to Binding Theory, the Principles it proposes allow descriptive basic facts. The purpose of Binding Theory is the following : how can we give an account of the process that leads to the interpretation of the nominal and pronominal elements in languages?

\subsection{Binding Principles: a general overview applied to French}

Observe the following French data :

3. a. Léon $_{\mathrm{i}} \mathrm{le}_{*_{\mathrm{i}} / \mathrm{j}}$ voit.

Léon him sees

b. Léon $\mathrm{se}_{\mathrm{i} /{ }^{*} \mathrm{j}}$ voit

Léon himself sees.

4. a. Léon ${ }_{\mathrm{i}}$ pense que Gertrude $\mathrm{e}_{\mathrm{j}} \mathrm{e}_{\mathrm{i} / \mathrm{*}_{\mathrm{j}} / \mathrm{k}}$ voit.

Léon thinks that Gertrude him sees

b. Léon ${ }_{\mathrm{i}}$ pense que Gertrude $\mathrm{je}_{\mathrm{j} / \mathrm{j} /{ }^{*} \mathrm{k}}$ voit.

Léon thinks that Gertrude herself/himself sees

It may be noted that a pronoun such as le should have disjoint reference in a given domain whereas the reflexive pronoun se must be linked in the same given domain.

Binding and referential disjunction are defined as follows : 


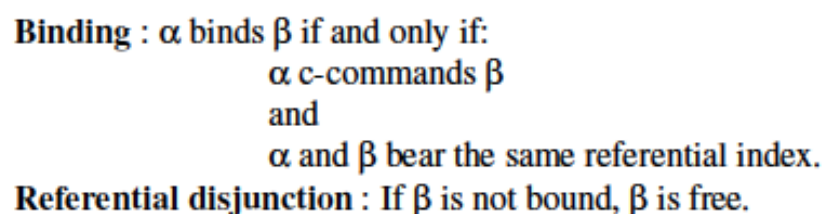
bound in its governing category, that is to say that it must bear the same index as its ccommanding antecedent in its governing category. In (3b) se is bound by Léon and in (4b), its governing category being the subordinate clause, it is bound by Gertrude. The following data can thus be explained with respect to Principle B :

Principle B : a B-pronoun must be free in its governing category.

The governing category represents the domain in which these principles apply.

Non-reflexive pronouns, $i l$, le, etc... fall under Principle B, which explains that in (3a), le cannot be coindexed with Léon which is located in its governing category and ccommands it, while in (4a), even though Léon also c-commands le, the coindexation is possible (and therefore the coreference also) because Léon is located outside the governing category of $l e$.

On the other hand, a reflexive pronoun like se is submitted to Principle A: it must be

In this framework, two principles account for the behaviour of pronouns, A-pronouns being reflexive and B-pronouns being non-reflexive :

Principle A : an A-pronoun must be bound in its governing category.

\footnotetext{
5. a. [Le fils de Léon $\left.]_{\mathrm{i}}\right]_{*_{*_{i}} / \mathrm{k} / \mathrm{k}}$ voit.
}

The son of Léon him sees

b. Léon ${ }_{\mathrm{i}}$ pense $\mathrm{qu}^{\prime} \mathrm{i}_{\mathrm{i} / \mathrm{j}}$ est génial.

Léon thinks that he is a genius

In (5a), le can refer to Léon, even if the two terms are located in the same governing category because Léon does not c-command le. In (5b), il may refer to Léon, Léon being outside of its governing category.

In the case of B-type pronouns, the freedom constraint does apply only within the governing category, and there is no binding constraint. For sentences (5), it is also possible for le and for $i l$ to have a reference other than Léon, which is noted by the indices $\mathrm{k}$ and $\mathrm{j}$ respectively. It is also the case for sentences (3a) and (4a).

However, Principle B does not predict anything when there is a dislocated constituent as in the following sentences :

$$
\begin{aligned}
& \text { 6. a. Léon }{ }_{\mathrm{i}}, \mathrm{il}_{\mathrm{i} / *_{\mathrm{j}}} \text { part demain. } \\
& \text { Léon, he leaves tomorrow } \\
& \text { b. Léon }{ }_{\mathrm{i}}, \mathrm{je} \mathrm{le}_{\mathrm{i} /{ }^{\mathrm{j}} \mathrm{j}} \text { vois tous les jours. } \\
& \text { Léon, I him see every day }
\end{aligned}
$$

18 Nevertheless, in these sentences the pronouns il and le necessarily refer to the dislocated element Léon. Léon is here outside the governing class, and it is situated in a nonargumental position, an A-bar position : this is called A-bar binding, but this phenomenon is in no way predicted by Principle B, though it is not banned by this principle. (However, Principle B does not explain why the resumptive pronouns obligatorily corefer to the dislocated constituent.)

Besides this point, the Theory of Binding also defines constraints for referential expressions, i.e. non-pronominal expressions. Here, the point to be addressed is why the 
following sentences are blocked, where the two occurrences of Léon refer to the same person:

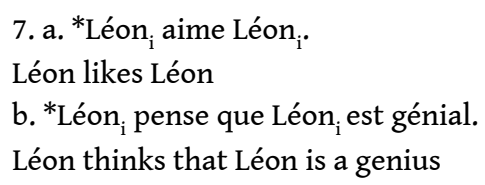

The constraint has to be stronger than for B-type pronouns, because as shown, the referential expression cannot bear the same index as a term which c-commands it, whether this term is in its governing category as in (7a) or outside of it, as in (7b). As soon as there is no c-command, the coindexation becomes possible :

8. La femme de Léon ${ }_{\mathrm{i}}$ pense que Léon ${ }_{\mathrm{i}}$ est génial.

The wife of Léon thinks that Léon is a genius

But unlike B-type pronouns, referential expressions may not be A-Bar bound by a

dislocated constituent :

9. a. * ${ }^{*}$ éon $_{\mathrm{i}}$,je pense que Léon ${ }_{\mathrm{i}}$ est génial.

Léon, I think that Léon is a genius

b.* Léon ${ }_{\mathrm{i}}$, je pense que [l'homme aux lunettes rondes $]_{\mathrm{i}}$ est génial.

Léon, I think that the man with round glasses is a genius

c. *[1'homme aux lunettes rondes $]_{\mathrm{i}}$, je pense que Léon ${ }_{\mathrm{i}}$ est génial.

The man with round glasses, I think that Léon is a genius

In the light of these data, we get Principle $\mathrm{C}$ of the Binding Theory, as it was stated

in Chomsky (1981):

Principle C : A referential expression must be free.

Indeed, the referential expression cannot bear the same index as another term under ccommand, whether this term is within its governing category or not and whether it is in an argumental position or not.

Principle $\mathrm{C}$ also blocks the following sentence where the pronoun il and Léon are coindexed and where il c-commands Léon:

10. ${ }^{*} \mathrm{Il}_{\mathrm{i}}$ pense que Léon ${ }_{\mathrm{i}}$ est génial.

He thinks that Leon is a genius

Thus the Principles A, B and C account for a large amount of data without resorting to the linear notion of "antecedence", in the strict use of the term, namely that the antecedent is "placed before", which is not always true as shown in the following sentences :

11. a. Quand $\mathrm{il}_{\mathrm{i}}$ dort, Léon $_{\mathrm{i}}$ ne supporte pas la lumière.

When he sleeps, Leon does not stand the light

b. $\mathrm{Il}_{\mathrm{i}}$ pense qu'il $\mathrm{i}_{\mathrm{i}}$ est génial, Léon .

He thinks that he is a genius, Leon

In (11a), il does not c-command Léon and Léon does not c-command il. Thus Principle B is respected for $i l$, that is $i l$ is free in its governing category and can refer to Léon. And on the other hand, Principle C is also respected for Léon as il does not c-command Léon and, consequently, Léon is free.

The Binding Theory has been central to research in the field of pronouns, proposing universal principles in the framework of Universal Grammar.

In the following section, we present the case of English copular sentences, which have been known for a long time as counter-examples for Principle C. But there are other wellknown counter-examples, in Thaï for example (cf. Lasnik \& Uriagereka 1988) where a sentence John likes John is possible. 


\subsection{Copular sentences as counterexamples of Principle $C$ ? The case of English} sentences. not the case. perfectly $\mathrm{OK}$. $\mathrm{John}_{\mathrm{i}}$, too.

The question that we wish to raise relates to copular sentences. Binding Theory is assumed not apply to copular sentences, though this type of sentences typically associate pronouns or referential expressions to pronouns or referential expressions : we speak here about the copular sentences denoting identification, identity and specification, according to the classification suggested by Higgins (1979), leaving aside predicational

12. a. Predicational structure : Beverly is a fine baker.

b. Specificational structure : The best pie-maker is Beverly.

c. Identity structure : Cicero is Tully.

d. Identificational structure : That woman is Beverly.

Briefly outlined, only the predicational sentence contains a non referential post-copula constituent, all other constructions are of the form XP1 is XP2, where XP1 and XP2 are referential. And referential terms must be able to be provided with referential indices, whether they are in a sentence with a copula or in another type of sentence. But connecting two referential expressions with the copula means that the same reference is given to both of them.

So, by applying indices to sentences $(12 b, c, d)$, we obtain the following representations :

13. a. [The best pie-marker $]_{\mathrm{i}}$ is Beverly $\mathrm{i}$.

b. Cicero $_{i}$ is Tully ${ }_{i}$

c. [That woman $]_{\mathrm{i}}$ is Beverly $\mathrm{y}_{\mathrm{i}}$.

Therefore, these sentences seem to go against Principle $C$ of Binding Theory, since for each one, the XP2 is c-commanded by the XP1 with which it is coindexed nonetheless. With another type of verb, while keeping the same global structure, the coreference is blocked and the sentences are banned :

14. a. *[The best pie-marker $]_{\mathrm{i}}$ likes Beverly $_{\mathrm{i}}$.

b. ${ }^{*}$ Cicero $_{\mathrm{i}}$ likes Tully $_{\mathrm{i}}$

c. *[That woman $]_{\mathrm{i}}$ likes Beverly $_{\mathrm{i}}$.

Thus on the basis of Principle C, the sentences $(12 b, c, d)$ should also be blocked, which is

Cecchetto \& Donati (2007 : 23-24) underline this fact :

The canonical formulation of Principle $\mathrm{C}$ makes an embarrassingly wrong prediction, since (17) should be a patent violation of Principle C. In fact, it is

(17) $\mathrm{He}_{\mathrm{i}}$ is $\mathrm{John}_{\mathrm{i}}$

Sentences like (17) are conveniently ignored in most discussions about Principle C.

Cecchetto \& Donati (2007 : 24, note 8) examine the various proposals :

Heim \& Kratzer (1998) propose that identity sentences be treated in a way similar to the " accidental coreference » that is present in the following sentence :

15. Everyone likes John. Bill likes John, Mary likes John, Robert likes John. $\mathrm{He}_{\mathrm{i}}$ likes

Example (17) is rather strange and Cecchetto \& Donati (2007) note that it is rather doubtful that their example (17) above could be of the same type as example (17) and that it could correspond to a case of accidental reference. 

that a sentence with identity can have a reading " $a=a$ ", which is not informative, and a reading " $a=b$ " which is informative $e^{3}$. She proposes to associate this reading " $a=b$ " with an analysis in terms of "guises" : the same individual can take various appearances, thus the sentence with identity would associate two different appearances or "guises" of the same entity and in this way is not blocked by Principle C (cf. also Schlenker, 2000).

Cecchetto \& Donati (2007:24, note 8) conclude thus and we agree :

However, even if Heim's approach could be extended to the informative reading, it would have nothing to say about the tautological reading of identity sentences, which is not ruled out, contrary to what the standard formulation of Principle C predicts. Furthermore, as acknowledged by Schlenker, this approach runs into the risk of opening a Pandora's box. If we introduce guises to explain the absence of binding violations in identity sentences - why couldn't we always introduce different implicit descriptions to refer to a given individual, thus circumventing any kind of binding-theoretic violation?

The problem of Principle C in copular sentences was raised by Fiengo \& May (1994), but quickly rejected. Their argument relates to the following sentence, which is their example (42) :

16. Griswold ${ }_{\mathrm{i}}$ is [the best cook of the town $]_{j}$

Fiengo \& May (1994 : 22) comment on this fact in the following way :

Now, since the referents of NP1 and NP2 are the same, (42) is true. But clearly, we do not want to impose it as a grammatical requirement that $\mathrm{i}=\mathrm{j}$, since then (42) would be analytic, because it would be a part of the meaning determined by its linguistic form that the NPs in this sentence corefer. When coupled together with the meaning of the verb be, this will make (42) in effect to the form $a=a$, and hence uninformative.

Thus, Fiengo \& May propose that the two XPs (NPs in their words) do not bear the same index, so that Principle $\mathrm{C}$ of Binding Theory is respected :

As we have stated matters, it only follows that a sentence of the form $N P_{i}$ be $N P_{j}$ (with $\mathrm{i}$ 溫 $\mathrm{j}$ ) does not carry as part of its meaning that $\mathrm{NP}_{\mathrm{i}}$ and $\mathrm{NP}_{\mathrm{j}}$ are coreferential by virtue of the interpretation of indices, just as it is not part of the indexically determined meaning of $\mathrm{NP}_{\mathrm{i}}$ saw $\mathrm{NP}_{\mathrm{j}}$ or $\mathrm{NP}_{\mathrm{i}}$ hit $\mathrm{NP}_{\mathrm{j}^{\prime}}$ (Fiengo \& May, $1994: 24$ )

And they conclude :

Thus, we conclude, an indexing of identity statements can be consistent with Principle C; hence they can be informative since coreference is not indexically required as part of their meaning. And since noncoreference is not the interpretation of noncoindexing, they can be true. (Fiengo \& May $1994: 24$ )

42 The analysis of Fiengo \& May concerning the copular sentences with identity seems to pose a certain number of questions among which : (i) what can be said about tautologies? and (ii) the indices are only a formalism for coreference, therefore indexing belongs to interpretation. Where and when does Principle $\mathrm{C}$ apply?

43 Under Fiengo \& May (1994), there would be no presupposition of coreference for the two terms since coreference is asserted by the sentence, and thus coreference would be external to binding.

4 This explanation seems to us to be a pirouette : considering Fiengo \& Mays's example (42), if we replace the verb is by likes the sentence is out if Griswold and the best cook of the town are the same person.

17. *Griswold ${ }_{\mathrm{i}}$ likes [the best cook of the town] 

and Binding Theory of Chomsky, applies in the interpretative component of syntactic derivation, it must, in our view, apply to all the sentences in the same way, and in the same way in all languages.

\subsection{Non-predicational copular sentences are not valid with est}

In French, identity-sentences with est are bad without a strong accent on est (we come back to this possibility section 3.3 ) :

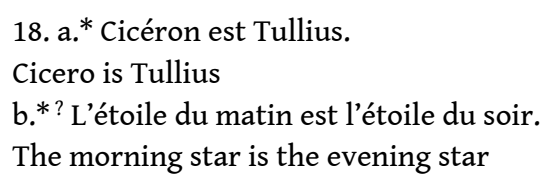

51 Morning star and evening star are two names of the same star in English, but not in French, where it is only called Venus. Thus this famous sentence, once translated into French, can become a predicational sentence with the DP l'étoile du soir which can be taken to be a predicate. This explains why it could be accepted by some speakers. 

following identificational sentences are impossible (except again with a strong accentuation on est, cf. section 3.3) :

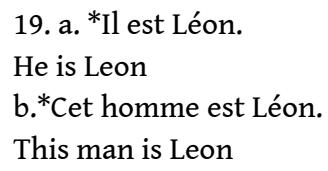

And specificational sentences are also banned :

20. a. *La meilleure cuisinière est Gertrude.

The best cook is Gertrude

b. 'Ce que j'aime est son humour.

What I like is his humor

It seems that the non-validity of these sentences can find a justification with Principle $C$ of Binding Theory. In all these examples, the post-copula term is referential and has the same reference as the pre-copula term which c-commands it : there is thus binding of the post-copula referential expression, which is impossible according to Principle $\mathrm{C}$, and the agrammaticality of these sentences naturally follows 4 .

If there is a generalization according to which Principle $C$ does not apply to nonpredicational copular sentences, then French would be a counter-example for this generalization. On the other hand, if Principle $\mathrm{C}$ applies to non-predicational sentences, then the French data is (partly) explained but the English is not. An argument in favor of the last option is the fact that we can find other languages with the same behaviour as French.

\subsection{Copular sentences in Polish and Russian}

For example, in Polish, an identity sentence is not easily acceptable with the only verb " jest" (cf. Citko, 2008), while the structures are possible either with the demonstrative to, or with to + jest ${ }^{5}$ :

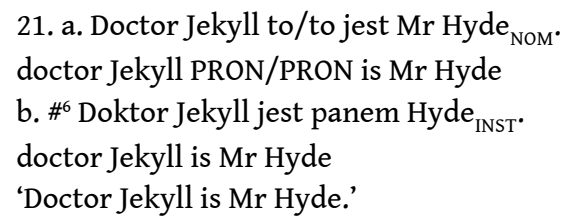

57 The same is true for specificational sentences (22) and identificational sentences (23) :

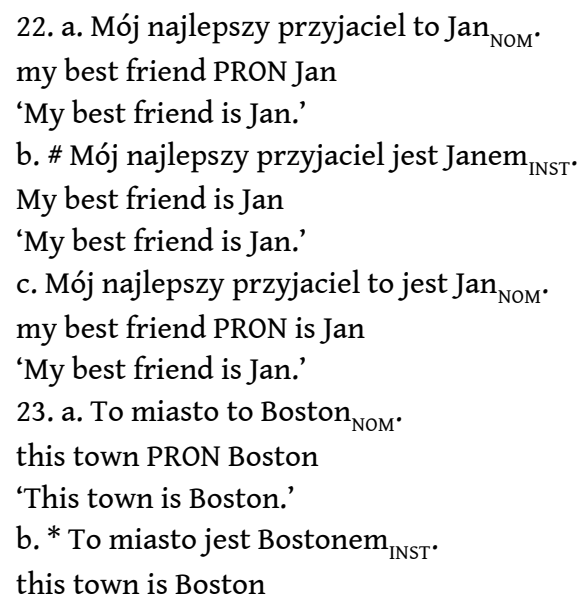




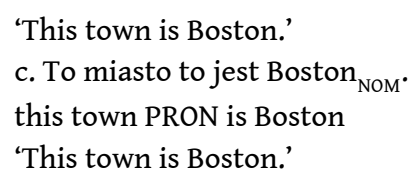

In Russian (cf. Geist, 2005) where there is no form for the verb is in the present tense ${ }^{7}$, we can observe the following contrast between the predicational sentence and the identity sentence in which the demonstrative eto is obligatory whereas it cannot be present for the predicational sentence :

24. identity :

Mark Twain - *ø/eto Samuel Clemens. (equative)

Mark T.Nom this Samuel C.Nom

'Mark Twain is Samuel Clemens.'

25. predicational :

Mark Twain - $\varnothing /{ }^{*}$ eto pisatel' po professii. (predicational)

Mark T. this writer Nom by profession

'Mark Twain is a writer by profession.'

But Russian specificational sentences do not accept the presence of eto (cf. Geist, 2007) :

26. specificational :

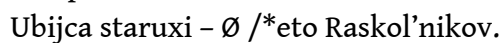

murdererNom of-old-lady this Raskolnikov

'The murderer of the old lady is Raskolnikov.'

Many studies have explored the Russian paradigm of copular sentences. Regarding what is at stake in the present discussion, the most surprising is the ban on eto for specificational sentences in Russian, while the presence of to is obligatory in Polish. Geist (2007) proposes that specificational sentences are reversed predicational sentences (cf. Moro, 1997), i.e. the predicate comes as the XP1, while the XP2 is referential. ${ }^{8}$

61 Thus in Polish as in Russian, the identity structures require a demonstrative, as it is also the case in French for the three types of non-predicational sentences:

27. a. Cicéron c'est Tullius.

Cicero CE is Tullius

b. L'étoile du matin c'est l'étoile du soir.

The morning star $\mathrm{CE}$ is the evening star

28. a. C'est Léon.

CE is Leon

b. Cet homme c'est Léon.

This man CE is Leon

29. a. La meilleure cuisinière, c'est Gertrude.

The best cook CE is Gertrude

b. Ce que j'aime c'est son humour.

What I like CE is his humour

Unlike what occurs for English is, the equation of two terms asserted by the verb est alone in French produces a non-valid sentence. It seems that it is also the case for the nonpredicational sentences with Polish jest. Thus, one cannot generalize the fact that the copular sentences contravene Principle $C$ and, it appears that it can be Principle $C$ which blocks the French sentences with identity, identification and specification (cf. 18-20) as well as the Polish $(21 b, 22 b, 23 b)$ and the Russian (24) sentences.

3 This is, in fact, the whole paradox of the non-predicational sentences : the asymmetry of language blocks the equation of two coindexed terms because of the c-command configuration. 
64 If we are on the right track, in the same configuration, if the two XPs do not bear the same index, then the sentence would be perfectly fine. An obvious example of this case is the following:

30. Aujourd'hui, on est lundi. $_{\mathrm{j}}$.

Today, one is Monday

This sentence is possible because on (meaning nous/we) and lundi do not have the same reference.

\subsection{The influence of prosody}

Identity sentences (18-19) can become acceptable with a strong stress on est, which results in a contrastive focus reading :

31. a. Cicéron EST Tullius. (a. pas Néron /b. pas Marcus) ${ }^{9}$

Cicero IS Tullius (a. not Nero/b. not Marcus)

b. L'étoile du matin EST l'étoile du soir.

The morning star IS the evening star

67 The same phenomenon is found for identification sentences. When the verb est bears a strong stress, the sentence is better and it gets a contrastive reading:

32. a. Il EST Léon ${ }^{10}$.

He IS Léon

b. Cet homme EST Léon. (a. pas cet autre homme/ b. pas Marcel)

This man IS Léon (a. not this other man/b. not Marcel)

68 For specificational sentences, even with a strong accentuation on est, the resulting reading is not straightforward:

33. a. La meilleure cuisinière EST Gertrude (pas Germaine).

The best cook IS Gertrude (not Germaine)

b. 'Ce que j'aime EST son humour (pas sa moustache).

What I like is his humor (not his mustache)

69 If the est is pronounced with a long accentuation and a growing stress on the end of the word and if est is followed by a pause, then we can obtain an acceptable sentence :

34. Le gagnant e $\mathbf{s} \mathbf{t}$ - Léon.

The winner is - Léon

70 If we add a colon, the result is better for reading :

35. Le gagnant e $\mathbf{s} \mathbf{t}:$ Léon

The winner is : Léon

71 Identity and identification seem much more difficult to save this way:

36. ? ? Il e s $\mathbf{t}$ : Léon

He is : Léon

37. ? ? Marcel est : M. Noël

Marcel is : M. Noël

Another example can be given, though judgements may vary:

38. *Le nombre de planètes est neuf.

The number of planets is nine

39. Le nombre de planètes est : neuf.

The number of planets is : nine

73 We come back to the colon in section 4, for it can also be used without the verb est in specificational non-verbal sentences. The colon could be viewed as an unrealized demonstrative $\left(c^{\prime}\right)$. 
74 As a consequence, it seems that specificationals have to get a special treatment among non-predicationals, though we assume that they belong to this class.

\subsection{Identity, identification and specification require the demonstrative $c^{\prime}$}

$$
\text { English : }
$$

41. $\mathrm{He}_{\mathrm{i}}$ is Leon . .

78 How can we explain the contrast between English and French ?

79 As we have seen, in French, the identity sentences (27), the identificational sentences (28) and the specificational ones in (29) are valid with the demonstrative $c e / c$ '. Many questions arise concerning French sentences with c'est, we will address only two of them here :

81 traditionally analyzed as dislocation structures in which $c^{\prime}$ anaphorises the dislocated constituent.

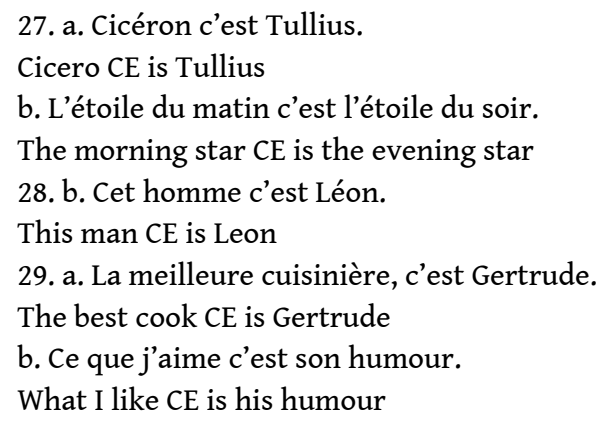

- is $c^{\prime}$ an expletive ? Sentence (28a) is generally considered as a presentational sentence in which $c^{\prime}$ is semantically empty. The demonstrative is also considered as an expletive in cleft sentences ${ }^{11}$.

\section{8. a. C'est Léon.}

Although we will not analyze here clefts and presentationals, our aim is to bring together all the c'est-sentences : whatever analysis is proposed for ' $c^{\prime}$, it should hold for all c'estsentences.

Let us concentrate first on sentences (27) and (28b) and let us assume that these sentences are derived from (18) and (19b) by dislocation whichever way dislocation takes place $^{12}$.

18. a.* Cicéron est Tullius.

Cicero is Tullius

b. ? L'étoile du matin est l'étoile du soir.

The morning star is the evening star 
19. b.* Cet homme est Léon.

This man is Leon index as the post-copula constituent that it c-commands : there would be A-Bar binding. However, the post-copula constituent is a referential expression and it cannot be either A-bound or A-Bar bound, it must be free, cf. (44) :

*44. Cet homme ${ }_{i}$, je vois Léon .

91 Thus we are left with a comparable problem to the one posed by English. Why can the post-copula XP2 have the same index as the XP1 in the structure XP1 c'est XP2, though XP1 c-commands XP2 ? Considering that XP1 is in an A-Bar position does not solve the problem for the XP2 : being referential, XP2 cannot be A-Bar bound under Principle C. sentences XP is XP, the two indices of the two XPs are different in syntax, assumption according to which the coreference would take place then on a semantic/pragmatic level. If we are right on this point, then the same applies to the sentences in XP1 c'est XP2. The two XPs are coreferential and one c-commands the other: the fact that the first XP is located in a non-argument position is not supposed to make the structure valid, since a referential expression must be free. TOPIC c'est FOCUS as proposed by Heycock \& Kroch (2002) for equatives in English. 

index : thus Principle $C$ does not apply between $c^{\prime}$ and XP2 in XP1 $c^{\prime} e s t$ XP2. As for the relationship between XP1 and XP2, the presence of the demonstrative blocks Principle C, by the configuration TOP c'est FOC where TOP and FOC are not argumental positions.

Some explanation is required here: considering that XP1 c'est XP2 is a structure of the type TOP c'est FOC, both TOP and FOC are A-Bar positions, not only the TOP position. In a dislocation structure Pierre $i{ }_{i} i_{i}$ est content, the A-Bar bound $i l$ is in an argument position. This is not the case of XP2 : it does not stand in an argument position. Thus, an element being in a FOC position escapes Principle C. Principle $C$ only applies to argumental positions. justification to the non-validity of the sentences in $X P_{R E F} e s t X P_{R E F}$ and makes it possible to explain the possibility of French $X P_{R E F} c^{\prime} e s t X P_{R E F}$. That calls into question the idea according to which Principle $C$ would not apply to copular sentences. Thus the problem shifts to the languages which, like English, seemingly contravene Principle C.

\section{Proposal}

\subsection{The Small Clause structure and referential indices}

If we consider that copular sentences are derived from a Small clause as a complement of the verb est, which is the analysis supported by most authors, then we have several possibilities to explore.

100 The intuition leading the present analysis is the exact opposite from Fiengo \& May (1994) : referential expressions come into the derivation with a reference, thus with an index. And it is a primitive of copular sentences to attribute the same index to both XPs; that means that the index is given at the bottom of the derivation, inside the Small Clause: either we get a Small Clause with a predicative XP2 or, when the XP2 is referential, it gets the same index as the XP1.

\subsubsection{Small Clause structure}

There are at least two possible structures for the Small Clause in literature ${ }^{14}$ :

(i) a flat or binary structure (cf. Moro, 1997) : 


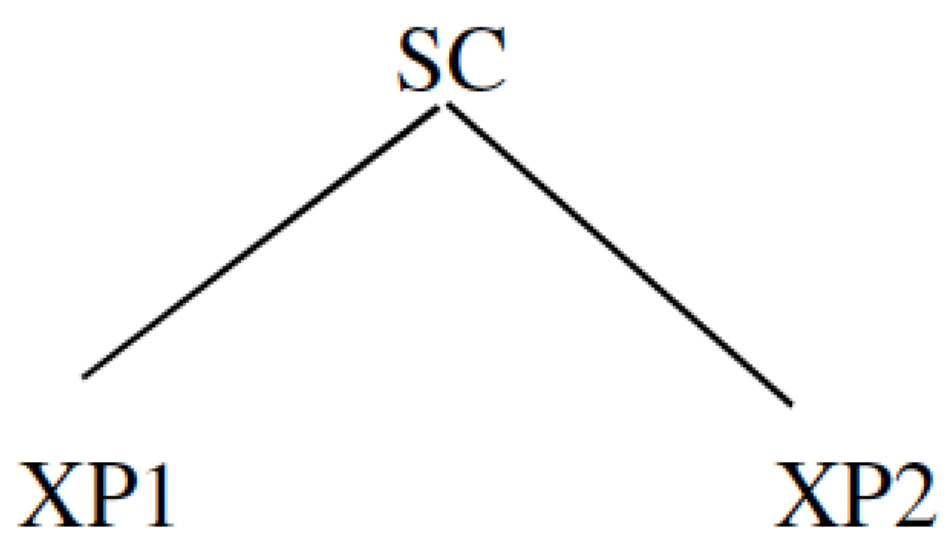

(8)

(ii) a structure based on the X-bar theory where there is a projection of a predicative head (cf. Bowers, 1993) :

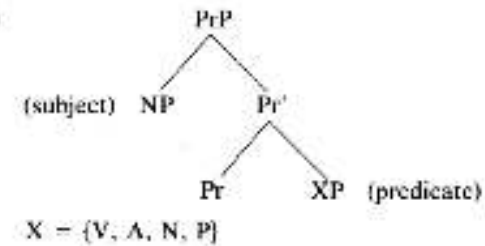

Below, we propose an argumentation which makes it possible to adapt in the same way the Small Clause structure for a sentence in est and for a sentence in $c^{\prime} e s t^{15}$.

On the basis of the binary representation of the SC (cf. Moro, 1997), the copular sentence (45a) can be derived, as shown in $(45 \mathrm{~b}, \mathrm{c})$ :

45. a. Cunégonde est stupide.

Cunégonde is stupid

b. est [ ${ }_{S C}$ [Cunégonde][stupide]]

c. Cunégonde $\mathrm{i}_{\mathrm{i}}$ est $\left[\mathrm{SC}_{\mathrm{SC}}\left[\mathrm{t}_{\mathrm{i}}\right][\right.$ stupide $\left.]\right]$

If we consider the flat structure SC, the only possibility for the c'est-sentences is that $c^{\prime}$ is either the first term or the second term of the Small Clause, leaving one of the referential $\mathrm{XPs}$ as a dislocated constituent :

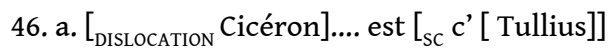

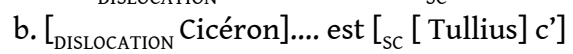

This is what is proposed in Belletti (2007) (cf. 47b) for sentence (47a) :

47. a. Ma passion c'est la lecture

My passion CE is the reading

b. Ma passion, [тP... [ Top [ Foc [Top [vp être [sc la lecture ce ]]]]]]

According to the flat SC structure, the first term is the referential constituent and the second the predicate. Thus, $c^{\prime}$ would be either referential in (46a) or predicative in (46b) and (47). If we take the first option, $c^{\prime}$ being referential, nothing would prevent us finding the subject pronoun $i l$ in this type of position : 
48. Cicéron... est $\left[{ }_{S C}\right.$ il [Tullius]] $\rightarrow *$ Cicéron, il est Tullius.

In this SC structure, the first term has no selection property, and thus we must reject this structure from a general point of view either for il-sentences or for c'est-sentences. First, only heads can have selection properties, and the flat structure SC offers no head. And, if we say that the first term of the SC selects the type of the second term, we could only say that $i$ selects a predicate, and $c$ ' selects a referential XP. But this is not the case, as shown in (49), where $c^{\prime}$ would select an adjective :

49. (Les sushis), c'est bon. ${ }^{16}$
(The sushis), CE is good

Nevertheless, this is the most commonly accepted description for XP1 c'est XP2 sentences. As we have already explained, if $c^{\prime}$ is referential, it bears the same index as the second term of the SC, a configuration blocked by Principle C.

Considering the second option, i.e. $c^{\prime}$ as a predicate, it cannot be maintained as $c e / c^{\prime}$ cannot appear in a predicate position ${ }^{17}$ :

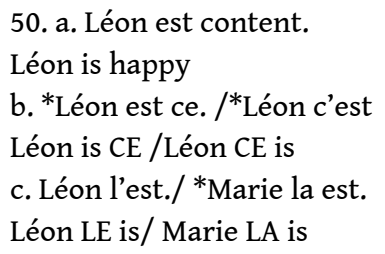

The last option, generally accepted for cleft and presentational sentences in French, is that $c e / c^{\prime}$ is an expletive subject (as proposed by Diessel, 1999) and is thus inserted directly into the subject position. Two types of objection can be raised for this option : (a) c'est-sentences are thus split into two types, those which have a referential $c$ ' and those which have an expletive $c^{\prime}$. This is the most common view for these sentences in the reference grammars ${ }^{18}$, but it raises many unsolved problems that reference grammars do not hide, especially Le Goffic (1993) ; (b) il can be an expletive subject in French, and, if an expletive subject was needed in this type of sentence, why would it not be il ? Even though the present study does not analyze cleft sentences, the purpose is to bring together the c'est-sentences, and to assume that they are all derived from the same pattern. Whatever role c' plays, it should be the same in all types of sentence. To conclude concerning the flat SC structure, it is unsatisfactory, neither in accounting for French data or in a general way, (see den Dikken (2006) for a detailed criticism of the flat SC structure). The concurrent analysis of the flat structure SC presents a predicative head, from which the SC is the projection (cf. Bowers, 1993). According to the author, this analysis has a double advantage :

(i) the Small Clause thus fits into the X-bar theory,

(ii) the predication is treated in a general way, since the proposed PredP ("PrP" for Bowers) projection works for Small Clauses as well as for any type of predication :

Bower (1993 : 595) 
(8)

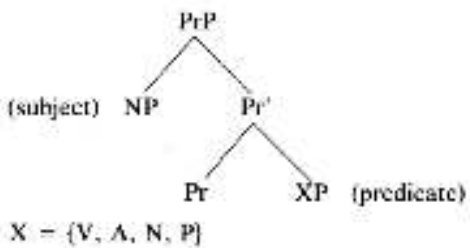

If we apply Bower's SC analysis to the predicational sentence (45a), we get the following derivation with an empty Pred head :
45. a. Cunégonde est stupide.
Cunégonde is stupid
51. a.. est $\left[{ }_{\text {Predp }}\left[\right.\right.$ Cunégonde] $\left[\left[_{\text {Pred }}\left[\left[_{\text {pred }} \varnothing\right][\right.\right.\right.$ stupide $\left.]\right]$

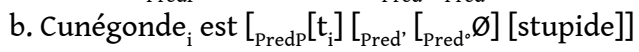

Literature has been proving for many years that the PredP analysis offers to take into account much more data than the flat structure : data from Scottish Gaelic (cf. Adger \& Ramchand, 2003), from Russian (cf. Geist, 2005, Markman, 2008, Baylin, 2004), from Polish (cf. Citko, 2008, Baylin 2004), from Haitian Creole (cf. Déprez, 2003), citing just some works among many. All the research referred to has been exploring the various possibilities given by the PredP SC structure with regard to these specific languages. For example, for Russian, Markman (2008) examines the hypothesis that the demonstrative eto is in the PredP head, but rejects it on the basis that the structure thus formed should be able to enter into Exceptional Case Marking verb constructions (with 'believe' or ' consider'), which is not the case ${ }^{19}$. Citko (2008) proposes that to is in the head of $\mathrm{T}$ while Bondaruk (2013) treats it as the head of PredP. Adger \& Ramchand (2003) analyze the pronominal $e$ that appears in non-predicational copula sentences in Scottish Gaelic as the complement of PredP. For Haitian Creole, Déprez (2003) considers that the se copula originates in the head of PredP.

When it comes to French data, fewer proposals have been made about copular sentences and PredP SC analysis. Most analyses have focussed on the alternation between il and $c^{\prime}$ (cf. Beyssade \& Dobrovie-Sorin, 2005, and Roy, 2006) for predicational sentences.

The general idea we want to outline is the following: with etre alone, the Pred head is filled by a $\varnothing$ head, whereas with c'est-sentences, the demonstrative $c$ ' is the head of PredP (along the lines of Déprez (2003) for se in Haitian Creole, and of Baylin (2004) for the demonstrative to in Polish).

Before presenting our proposal, let us describe Perelstvaig (2001)'s analysis. She proposes that non-predicational sentences have a binary SC structure ("bare", in her words) and that predicational ones get a PredP SC structure ("rich"). Hence, she assumes that, in non-predicational sentences, the two referential XPs come with the same index but are not blocked by Principle $\mathrm{C}$ because of the mutual c-command of the two XPs. On the other hand, in the PredP SC, the first XP c-commands the second, and if the second XP is referential, as they both get the same index, the sentence is blocked by Principle C. Consequently, this configuration would be good only if the second XP is predicative. This analysis is coherent and has the advantage of taking into account coreference and Principle C, but it has some weaknesses. One of them is that it cannot take into account French data : in French, when there are two referential XPs, we obligatorily get a c'estsentence. If the demonstrative is to be inside the $\mathrm{SC}$ as a referential term, then we can explain the possibility of $c^{\prime}$ and XP2 having the same index because of the mutual c- 
command, but the XP1 would be a dislocated term and thus would bear the same index and would c-command both $c^{\prime}$ and XP2. This would cause the derivation to crash.

Another problem with Perelstvaig (2001)'s analysis is that it does not explain the topic/ comment structure of the non-predicational sentences (a fact on which a lot of analyses agree). And lastly, it seems undesirable to have two types of structure for the Small Clause. If one takes the option of SC as a projection of a functional head, then it should be the same configuration for all SCs. The differences that have been noted between copular sentences have to fit into an analysis within the same premise.

Our proposal is the following : the verb est takes a Small Clause as complement, and if we assume Bowers (1993), this Small Clause can have an X-Bar structure, and be a predicative phrase with a predicate head. Est can select two types of Small Clause, one headed by an empty head, the other one headed by the demonstrative.

52. a. être $\left[_{\text {PrédP }} X P\left[{ }_{\text {Préd }}\left[_{\text {préde }^{\circ}} \varnothing\right][X P]\right]\right]$

b. être $\left[_{\text {PrédP }} X P\left[_{\text {Préd }}\left[{ }_{\text {préd }^{\circ}} c^{\prime}\right][X P]\right]\right]$

The selection properties of the two heads guarantee the fact that in (52a) the complement is a predicative XP, while in (52b) the complement is a Topic.

identity statement in the following way :

53. ${ }^{*}$ est $\left[_{\text {predp }}[\text { Cicéron }]_{i}\left[\left[_{\text {red' }}\left[{ }_{\text {pred }} \varnothing\right][\text { Tullius }]_{i}\right]\right.\right.$

\subsubsection{Evidence from non-verbal sentences}

This clearly means that Binding Principles apply as soon as the Small clause is inserted as the complement of verb être. We might even go further by saying that Binding Principles apply as soon as the Small Clause is formed. It seems to be the case that some non-verbal sentences could be viewed as instances of Small clause, and what we find for non-verbal sentences seems to be the same as for est-sentences : the XP2 can only be predicative. This is what we find in titles :

54. [Ban Ki-moon[ø [reconduit à la tête de l'ONU]]] (cf. Le Monde site, 21/6/2011)

Ban Ki-moon re-elected at the head of UNO

131 It seems to be difficult to find a referential XP2 in this type of structure, just as for estsentences. This was already noted by Vinet (1993) for titles, and she gives the following example :

55. *Depardieu, Jean de Florette

Depardieu, Jean de Florette

Here, the comma shows that something else has happened to the derivation of these titles. But we must notice that sentence (55) would be even worse without the comma (cf.56), and that it could become valid with a colon, as it is the case for (57) :
56. *Depardieu Jean de Florette
Depardieu Jean de Florette
57. Depardieu : Jean de Florette
Depardieu : Jean de Florette

Titles and in a more general way non-verbal sentences can be analyzed in the light of our proposal, but we leave this subject to further research, and we would just like to mention here that sentences with a colon could be seen as non verbal counterparts of c'est sentences. 
134 It is interesting to note here that only specificationals and partial identity (cf. AmaryCoudreau, 2014) can undergo the "colon effect", as it is called by Blanche-Benveniste (2010), (cf. 58) : strict identities and identification are banned with a colon, as shown in (590).

58. a. La meilleure cuisinière : Gertrude.

The best cook : Gertrude

b. Emmanuel Macron : le Président des Français.

Emmanuel Macron : the French President

59. a. *Xavier : M. Lemaréchal

Xavier : Mr. Lemaréchal

b. *Lui : Léo

Him : Leo

c. ${ }^{*}$ Cet homme : Léo

This man : Leo

Thus, putting aside details of a possible analysis of non-verbal sentences, it seems possible to consider that the different indices appear at the stage where the Small Clause is built. This would explain on the same basis the impossibility of strict identity and identification titles without copula, and the behaviour of est-sentences. On the other hand, it also confirms that specificationals (and partial identities) are to be treated separately from the set of equatives, though we maintain that they undergo the same (basic) analysis as equatives. Specificationals, however, need further research.

Coming back to Principle $C$, if we cannot find non-verbal equative sentences (with the mentioned exceptions), we can thus assume that XP1 and XP2 come up in the Small Clause with referential indices, and Principle $C$ blocks them at this very early stage.

\subsection{The derivation}

analysis goes against classical analyses in French, where $c$ ' is treated as referential in XP1 c'est XP2, whereas $c^{\prime}$ is considered in most research as an expletive in presentationals as well as in clefts. The present study does not explore clefts, leaving this topic for further investigation, but it predicts that all c'est-sentences, XP1 c'est XP2, presentationals and clefts, are based on the same underlying structure : the Pred head c' takes a Topic as complement, while the specifier seems to be a Focus.

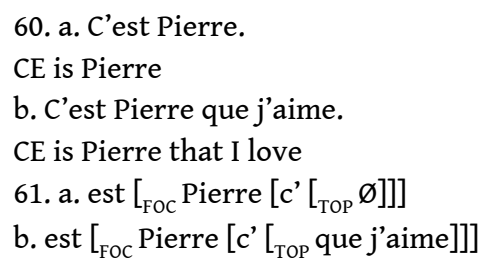

We do not focus on the derivation of XP1 c'est XP2 sentences here, but what is at stake is that the Topic complement of $c^{\prime}$ in the SC ends up as the specifier of a Topic projection at the top of the tree, while the specifier of PredP lands in the specifier of the Focus projection. Sentence (62) can be derived in the way described by Tree 1 :

62. Léon, c'est mon ami.

Tree (1) : 


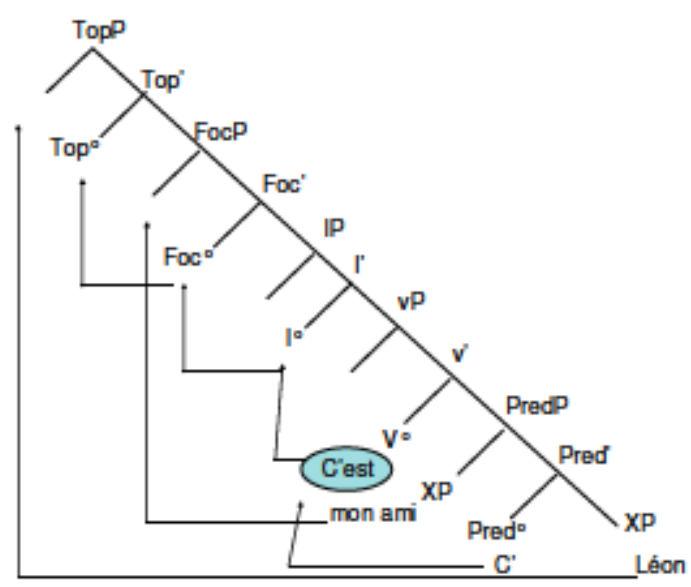

140 This could be viewed as the inversion analysis of Moro (1997) : the complement of PredP ends up as the first XP in surface structure : but, in our view, the complement of PredP climbs to [Spec, TopP] and not to [Spec, IP] as in Moro (1997).

This derivation needs special attention ${ }^{20}$, which is beyond the scope of this work, but it can explain why the order c'est XP2 $2_{F O C} X P 1_{\text {TOP }}$ is possible when the Topic does not move overtly :

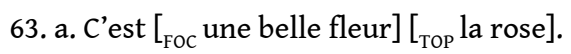

$\mathrm{CE}$ is a nice flower the rose

b. [TOP La rose], c'est [Foc une belle fleur].

The rose $\mathrm{CE}$ is a nice flower

c. est [ [ ${ }_{\mathrm{FOC}}$ une belle fleur [c' ${ }_{\text {TOP }}$ la rose $\left.\left.]\right]\right]$

Clefts sentences have a structure where the Topic part stays in its original position inside the SC and cannot move, a fact that needs to be explored.

Thus the surface order of non-predicational c'est-sentences is the reverse order of the Small Clause :

64. a. est [Pierre [c'[mon ami]]] 圆 Mon ami, c'est Pierre.

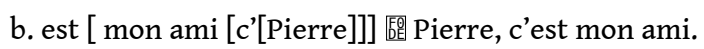

\subsection{Negation and modality}

144 If there can be reference apart from the sentence, and thus of syntax, (one can just designate Léon! as referring to a particular individual), the construction of the coreference applies within syntax, the interpretative component being the last chain link. Indeed, with the negation, the problem no longer arises; except for specificational pseudoclefts (cf. 65f) :

65. a. Cicéron n'est pas Tullius.

Cicéron is not Tullius

b. L'étoile du matin n'est pas l'étoile du soir.

The morning star is not the evening star

c. ?Il n'est pas Léon.

He is not Léon

d. Cet homme n'est pas Léon.

This man is not Léon

e. La meilleure cuisinière n'est pas Gertrude.

The best cook is not Gertrude 
f. ? ?Ce que j'aime n'est pas son humour.

What I like is not his humor

It should be noted here that, for some people, negation or modality improve sentences with the subject il a little bit but not enough to make them acceptable (cf. 65b). It shows that sentences *il est DP might have more constraints than the others : the same native speaker who does not accept il est Léon easily, even with negation or modality, would tend to accept sentence like Cet homme est Léon.

The behaviour of specificational pseudoclefts in French seems different from other specificational sentences : pseudoclefts are better with negation or modality (cf. 65f), but still not very natural. This could mean that something more occurs in this type of sentence. This is also the case in English where specificational pseudocleft sentences exhibit special characteristics, notably what is called "reconstruction effects" (cf. Schlenker, 2000), den Dikken, 2006, Mikkelsen, 2011). One of these reconstruction effects concerns the behaviour of the post-copula pronouns with respect to Binding Principles. ${ }^{21}$

With the negation of the identity, the two terms of the copular sentence are explicitely posed as not having the same index and can thus appear in this configuration. In the same way, epistemic modality seems to play a role :

66. Cicéron peut/doit/semble être Tullius.

Cicéron may/must/seems to be Tullius

The identity of the two terms is given as possible or put into question with pouvoir, devoir or sembler, and consequently it is not posed. The two terms do not carry the same index, and the configuration under c-command becomes possible.

Adding epistemic adverbs or adverbial phrases also gives grammatical sentences :

67. a. Cicéron est peut-être/sans doute/sûrement Tullius.

Cicéron is maybe/without doubt/surely Tullius

Therefore, any assumption made about the est-sentences must be able to take into account these facts. Negation and epistemic modalities seem to put into question the exact index and, as a result, legitimate est-sentences with a referential XP2.

To draw a more complete picture, we should also add another fact: the ban on nonpredicational sentences with être (be) seems limited to the present tense. The future and past tenses (but in a less evident manner) do not display the same facts :

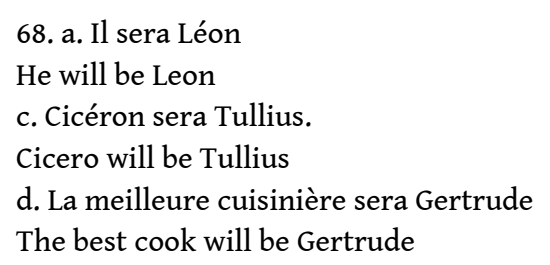

Here, it seems that, at speech time, the two XPs are not coindexed, and thus the sentences are valid. It is predicted that they will be one and the same, but at the moment the sentences are uttered, they are not.

What is at stake here is the change in the referential index of XP2, depending on the presence of negation, modality and non-present tense. How can this be processed in the derivation? How can negation, modality and tense change the referential index ? From a descriptive point of view, we can represent the subjacent structure of these sentences in the following way :

$$
\begin{aligned}
& \text { 69. a. n'est pas }\left[{ } _ { P \text { rédP } } X P 1 _ { i } \left[\left[_{P r e ́ d}\left[\left[_{P r e ́ d} \varnothing\right]\left[X P 2_{j}\right]\right]\right]\right.\right. \\
& \text { b. est Modality/Tense }\left[{ }_{P \text { rédP }} X P 1_{i}\left[{ }_{P \text { réd }}\left[{ }_{P \text { réd }} \varnothing\right]\left[X P 2_{j}\right]\right]\right]
\end{aligned}
$$




\subsection{Embedded sentences and the referential value of il}

Pierre is Paul

This brings us to an apparent counter-example: il est $X P_{\text {ref }}$ seems to be valid when embedded in a matrix clause.

Let us observe the following contrast :

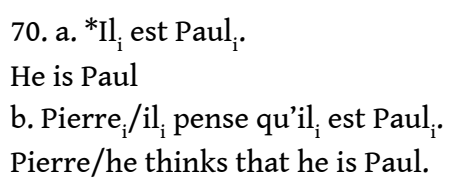

This contrast is specific to the subject $i l$, because it does not show up with other types of third person subject.

71. a. *Pierre est Paul.

b. ?Marie pense que Pierre est Paul.

Marie thinks that Pierre is Paul

72. a. ${ }^{*}$ Le voisin est Paul.

The neighbor is Paul

b. ?Marie pense que le voisin est Paul.

Marie thinks that the neighbor is Paul

Some speakers seem to accept the sentence (71b). This fact can be explained in the following way : if Marie thinks that Pierre is Paul, it means that in fact Pierre is not Paul, thus Pierre and Paul do not carry the same index, and the sentence becomes valid. Thus the matrix verb penser can have scope over the indices inside the embedded clause. But, it could be the case that Marie thinks that Pierre is Paul and that Marie is right in her belief, in which case Pierre and Paul have the same index, and the sentence is banned.

Coming back to the contrast given in (70), one possible way to explain it is the following: based on Pollock (1983), it is argued that the post-copular DP can assign a $\theta$-role to $i l$, only if $i l$ has an actual reference ${ }^{22}$. Pollock (1983) makes a split between virtual and actual reference of $i l^{23}$, saying that $i l$ only has a virtual reference but can acquire an actual reference if its antecedent receives a $\theta$-role in an independent way. This blocks (70a) where $i l$ has no antecedent in the sentence, and explains (b) where $i l$ has an antecedent, Pierre/il, which receives a semantic role from the matrix verb pense. Hence $i$ only has a virtual reference in (70a) while it gets an actual reference in (70b). Actual reference of $i$ could bring it up to the same ranking as deictics, although this needs to be checked in another way. Dislocation (cf.73) is predicted to be banned because the antecedent does not get a $\theta$-role on independent ground :

73. *Pierre, il est Paul.

Pierre, he is Paul

\subsection{What about English copular sentences?}

So, why don't English copular sentences exhibit the same behavior as French ones?

Our proposal for French was first inspired by the analysis of Heycock \& Kroch $(1999,2002)$ for English. For these authors, specification, identity and identification sentences can be subsumed under equative sentences. They split Higgins's taxonomy into two groups : equative and predicational sentences, and propose two subjacent SC structure types : one 
for predication and one for equatives. For Heycock \& Kroch (1997), the equative SC has a functional head which is absent in the predication SC.

The split proposed by Heycock \& Kroch $(1999,2002)$ is consistent with the French data : specification, identification and identity sentences exhibit the demonstrative $c$ ' while predicational sentences do not. Therefore, we can say that c'est-sentences correspond to equatives while est-sentences match up with predicational sentences.
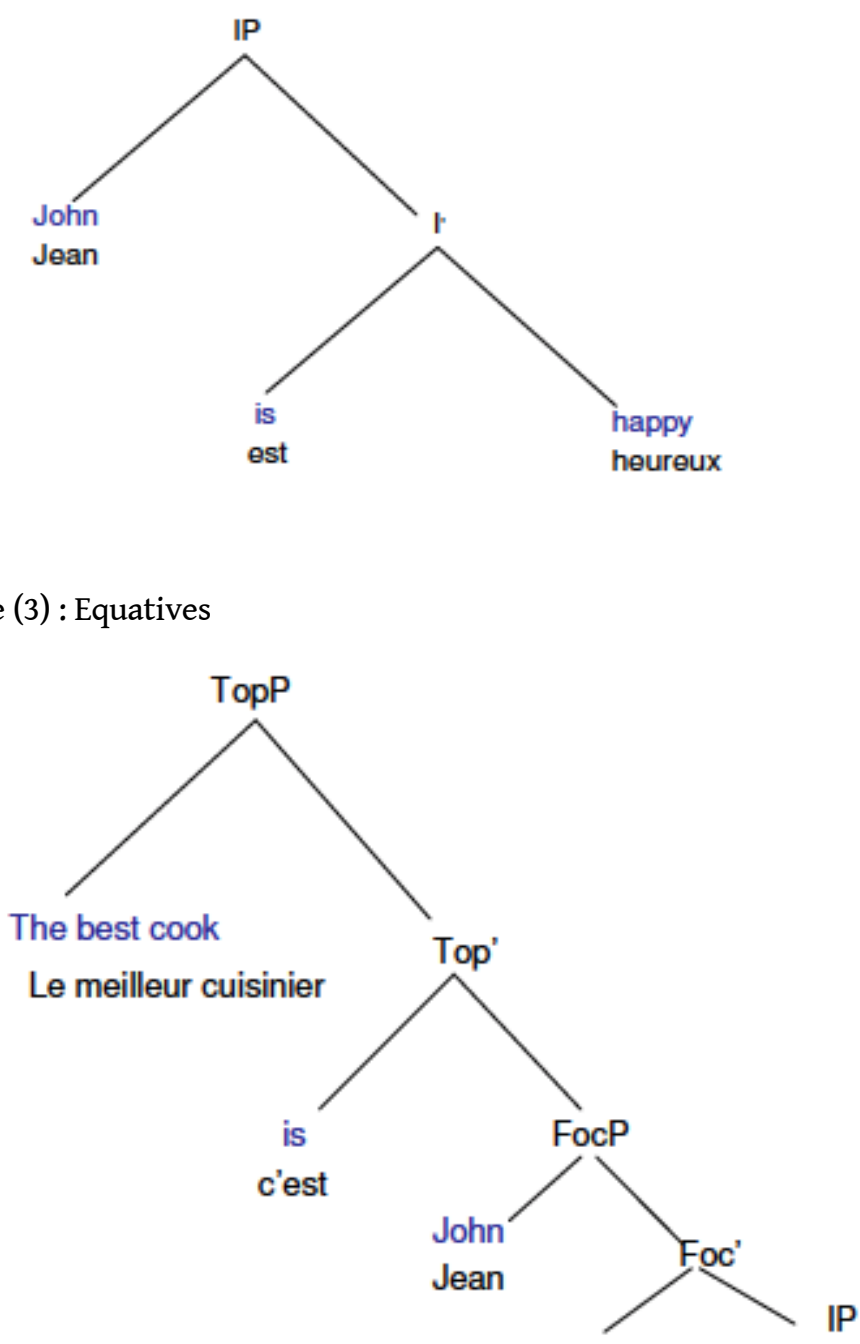

These two types of sentences clearly have different subjacent structures, and give material evidence for Heycock \& Kroch's hypothesis. Under our view, this split is syntactic and goes against the predication inversion analysis for specificational sentences (cf. Mikkelsen, 2002, 2004, Heggie, 1988). Specificational c'est-sentences are treated as equatives and are not derived from predicational sentences. But this does not mean that there is no difference between specification, identification and identity : each of these subtypes for equatives show semantic peculiarities that should be derived from the nature of the two XPs.

Let us consider the following sentence in English :

74. Bill is my friend. 
Tree (5) :

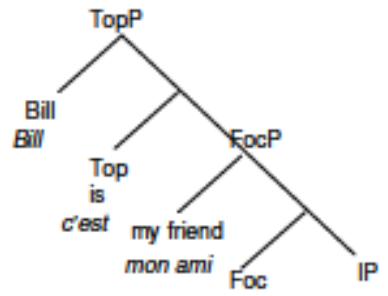
sentences (75a) and (75b) :

75. a. Bill est mon ami.

b. Bill c'est mon ami. ${ }^{24}$ :

Tree (4) :

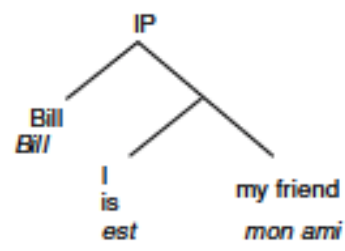
explanation :

76. a. *Il est Léon.

b. He is John.

In English (74) is ambiguous, my friend can be predicative or it can be considered as referential yielding an identification reading. (74) can be translated into French by both

In French, (75a) can only be predicational, as an est-sentence can only select an SC with a predicative XP2 and (75b) is an identification sentence. This can be represented as follows be a Topic Marker (cf. Lee, 2002) whereas French est cannot play this part alone. Est needs the support of the demonstrative $c^{\prime}$ to fill the head of Topp.

Coming back to the contrast noted in (a-a), and repeated bellow, there has to be an

Could (76b) be explained on the ground of the Topic is Focus structure? In English, as in French, he/il is supposed to be nominative, then it should be in the [Spec, IP] position. But it should be noted that English he and French il have different properties, among which he can be used as indexical with pointing, where it is not possible to use pointing for $i$. Thus, he could occur in a non-subject position, namely a specifier-topic position. But the topic position has to be projected and needs a head. "The fact is, is that the present sentence gives an answer". We find double is constructions in English ${ }^{25}$, so the first is is usually said to be in the head of Topic (cf. O'Neill, 2012). 


\section{Consequences and perspectives}

The present study provides an innovative view on French copular sentences and sheds a new light on constraints to the referential status of arguments as predicted by G\&B.

This study has shown that Binding Principle $C$ does apply to French copular sentences, and that it explains the ban on XP1 est XP2 where XP2 is a referential expression in French. When the XP2 is referential, i.e. when the sentence is not predicational, the presence of the neuter demonstrative pronoun $c^{\prime}$ is obligatory.

6 In this way, French data gives evidence for the split between predicationals and equatives as proposed by Heycock \& Kroch $(1999,2002)$ : the former have an est-sentence configuration while the later have a c'est-structure. In our view, this split is due to the difference of structure of these two types of copular sentence : though both are construed with a Pred(icative) projection SC, along the lines of Bowers (1983), est-sentences take an empty Pred head, while c'est-sentences have the demonstrative c' as Pred head.

77 The PredP head c' selects a Topic complement, while it seems to be blind for its Focus specifier. Thus, we obtain an analysis à la Moro (1997) for non-predicational sentences, in the sense that the complement of the SC moves to the first position. However, in our view, this analysis applies to all equatives (specificationals, identities and identifications) and not only to specificationals as in Moro's proposal (1997). In Moro's view (1997), the specificationals are reverse predicationals, i.e. the predicative complement moves to the specifier of IP. The present analysis assumes two different structures for predicationals, on the one hand, and for equatives, on the other hand.

We have compared French data to other languages that exhibit a pronoun in nonpredicational copular sentences, and especially, those which have a demonstrative pronoun in these contexts, Russian and Polish. It does not seem exceptional that a demonstrative is at work in such a type of structure (cf. Diessel, 1999 and Rutkowski, 2006 $\left.{ }^{26}\right)$, given that in these languages, as in French, est-sentences cannot get a referential XP2 (with the exception of specificationals in Russian), due to Binding Principle C, in our view. We suggest that to in Polish and eto in Russian could originate in the Pred head position of the Small Clause, as it is the case for French c'. This goes against Markman (2008) for Russian eto : she proposes inserting eto directly in the specifier of the Topic projection at the top of the derivation. Another position is the one defended by Baylin (2004) and Bondaruk (2013) putting éto/to into the head of PredP F. Hence, in the present study, we agree with Markman's (2008) analysis that eto/c' is the head of the TopP, but it is not directly inserted in this position, it is the head of PredP, which moves up into Topp.

9 In a general way, demonstratives seem to have some special ability with regards to topichood : in Demol \& Tobback (2010), it is noted that ce brings a topic shift, while, in Moltmann (2013), the author analyzes the bare demonstratives as involving reference to perceptual features or "tropes". Certainly, more has to be said about this relationship between demonstratives and the structure Topic/Focus.

In addition to this point, the specific case of French specificational sentences needs to have further development : we have seen that, despite the fact that they can undergo the same analysis as other c'est-sentences, they seem to exhibit a particular behavior with regards to non-verbal sentences: we can get specificational reading of non-verbal sentences with a colon and without $c^{\prime}$, something that is not possible with (strict) 
identities nor with identification. Furthermore, we can get a specificational sentence with est alone, with a long intonation on est and a pause after.

77. a. Le gagnant : Léon

b. *Marcel : M. Noël

c. *Il : Léon

78. Le gagnant est : Léon

We propose that the "colon effect" could be the result of a non-lexicalized DEM head. But then, why could this DEM PredP head remain unrealized for specificationals and not for other equatives? This question needs to be addressed.

Another issue that has not been treated here is the problem posed by sentences of the form (XP) c'est adjective. In our view, they should be analyzed the same way as other c'estsentences, and, thus, the adjective should be in focus position. This proposal needs further development and goes against the traditional alternation between c'est + adjective and il est + adjective (cf. Roy, 2006, Beyssade \& Dobrovie-Sorin, 2005). Hence, this means that XP c'est adjective is not to be analyzed as predicational, but as specificational ${ }^{27}$.

\section{Conclusion}

In conclusion, although in the literature Principle $C$ of Binding Theory is taken not to apply to copular sentences, we have shown that this Principle applies to French copular sentences. Indeed, if Principle $C$ is a general principle, it must also apply to this type of sentence : a referential expression must be free, i.e. it cannot carry the same reference index as another (pro) nominal expression which c-commands it.

Therefore, Principle $C$ explains why there can only be predicational est-sentences, while equative sentences exhibit the presence of the demonstrative $c^{\prime}$. The equative c'estsentences yield a surface structure of the form Topic c'est Focus in the way proposed by Heycock \& Kroch $(1999,2002)$ for English. Topic and Focus being non-argumental, Principle C cannot apply. Both est-sentences and c'est-sentences are derived from PredP Small Clauses, but while the former takes an empty head $\varnothing$ as Pred $^{\circ}$, in the latter, the demonstrative $c^{\prime}$ is the head of PredP. We can easily derive the difference between the two types of SC : the $\varnothing$ head takes an predicate as complement, while $c$ ' selects a topic as complement.

I further assume that both referential XPs come up in the Small Clause with the same referential index (as Perelstvaig, 2001), on the basis of non-verbal copular sentences: there can be no equative non-verbal sentences, because both XPs already have the same index and, under the PredP SC analysis, one XP c-commands the other.

In the case of negation/modality/non-present tense, the PredP SC is the complement of Neg or Mod or T head(s) that permit the switching of one of the indices, thus satisfying Principle C. The same is true when there is epistemic modality, the identity is put into question and the coreference is not assumed, hence here again the indices are different. We did not explore the tense problem in detail, but if something was something else or if something will be something else, it means that at utterance time both XPs are not the same and thus do not have the same index.

187 Based on the validity of Principle $\mathrm{C}$ for copular sentences, the present study draws a very simple picture of copular sentences in French, which explains French data on general 
grounds, and fits into the general hypothesis on copular sentences and into Binding Theory.

\section{BIBLIOGRAPHIE}

Adger, D., \& Ramchand G., 2003. « Predication and Equation ». Linguistic Inquiry, 34.3, 325-359.

Amary-Coudreau V., 2012. «(XP), c'est terrible. Un cas de phrase spécificationnelle », SHS Web of

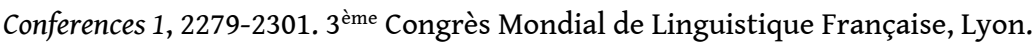

Amary-Coudreau V., 2014. «Identité stricte ou partielle et identification. Comment les identifier ? »SHS Web of Conferences 8, 2295-2312. $4^{\text {ème }}$ Congrès Mondial de Linguistique Française, Berlin.

Bailyn J. F., 2004. « Overt Predicators ». Journal of Slavic Linguistics, 10 (1-2), 23-52

Belletti A., 2005. «Answering Strategies. A View from Acquisition ». In : Baauw S., Drijkoningen F. \& Pinto M. (Eds.), Romance languages and linguistic theory 2005. Benjamins Publications, Amsterdam/Philadelphia, pp. 19-38.

Beyssade C. \& Dobrovie-Sorin C., 2005. «A Syntax-based Analysis of Predication ». SALT XV.

Blanche-Benveniste C., 2010. « Les pseudos-clivées et l'effet deux points ». In : M.J. Béguelin, M. Avanzi, Corminboeuf G. (Eds.), La Parataxe. Bern, Peter Lang, pp. 185-218.

Bondaruk A., 2013. Copular Clauses in English and Polish. Structure, Derivation and Interpretation. Wydawnictwo KUL, Lublin, str. 373

Bowers, J., 1993. « The Syntax of Predication ». Linguistic Inquiry 24, 591 - 656.

Cecchetto C. \& Donati C., 2007. « On labeling : Principle C and head movement». In : Vincenzo Moscati (Ed.), CISCL Working Papers on Language and Cognition, Vol1. STiLStudies in Linguistics, pp. 16-37.

Chomsky N., 1981. Lectures on Government and Binding : The Pisa Lectures. Holland : Foris Publications. Reprint. 7th Edition. Berlin and New York : Mouton de Gruyter, 1993.

Chomsky N., 1995. The Minimalist Program. MIT Press, Cambridge, Mass.

Clech-Darbon, A., Rebuschi G. \& Rialland A., 1998. « Are There Cleft Sentences in French ?» In : Rebuschi G. \& Tuller L. (Eds.), The Grammar of Focus. Amsterdam : Benjamins, pp 83-118.

Citko B., 2008. « Small Clauses Reconsidered : Not That Small and Not All Alike ». Lingua 118, 261-295.

De Cat C., 2004. « Dislocation without Movement ». In : Shaer B., Frey W., Maienborn C. (Eds.), Proceedings of the Dislocated Elements Workshop. ZAS Berlin, vol. 35.12, pp. 77-109.

Demol A. \&Tobback E., 2010. « A French Classical Revisited : the Distribution of IL and CE in Copular Sentences ». Studies van de BKL.

Déprez V., 2003. « Haitian Creole se : a Copula, a Pronoun, both or neither». In : Adone D. (Ed.), Recent Developments in Creole Studies. Max Niemeyer Verlag, Tubingen, pp. 135-173. 
Diessel H., 1999. « The Morphosyntax of Demonstratives in Synchrony and Diachrony ». Linguistic Typology 3, 1-49.

Dikken, M. den, 2006. Relators and Linkers. The Syntax of Predication, Predicate Inversion, and Copulas. Cambridge, MA : MIT Press.

Fiengo R. \& May R., 1994. Indices and Identity. MIT press.

Foulet L., 1935. « L'extension de la forme oblique du pronom personnel en ancien français ». In Romania, t. 61, 237-315, 401-463

Foulet L., 1936. « L'extension de la forme oblique du pronom personnel en ancien français ». In Romania, t. 62, 27-91.

Frege, G., 1892. « Über Sinn und Bedeutung». Zeitschrift für Philosophie und philosophische Kritik 100, 25-50.

Geist L., 2005. « Copular Sentences in Russian vs. Spanish at the Syntax-Semantics Interface». In : Ebert C. \& Endriss C. (Eds.), Proceedings of the Sinn und Bedeutung 10 : Annual meeting of the Gesellschaft für Semantik, October 13-15, 2005 (ZAS Papers in Linguistics 44). Berlin : ZAS, pp. 99-110.

Geist, L., 2007, « Predication and Equation in Copular Sentences : Russian vs. English ». In : Ileana Comorovsky I. and von Heusinger K. (Eds.). Existence : Semantics and Syntax, pp. 79-105.

Geist L., 2008. « Wieviel Verb braucht ein russischer Satz ? Überlegungen zur Nullkopula ». In : Junghanns, U. (Ed.), Linguistische Beiträge zur Slavistik. XIII. JungslavistInnen-Treffen Leipzig 2004. München : Sagner, pp. 123-141.

Hatcher A. G., 1948. « From ce suis je to c'est moi : the EGO as subject and as predicate ». In Old French. PMLA, t. 63, 1053-1100.

Heggie L., 1988. The Syntax of Copular Structures. Doctoral dissertation, University of Southern California, Los Angeles.

Heim, I., 1998. « Anaphora and Semantic Interpretation : A Reinterpretation of Reinhart's Approach ». In : Sauerland U. and Percus O. (Eds.), The Interpretive Tract. MIT Working Papers in Linguistics 25, pp. 205-246.

Heim, I. \& Kratzer A., 1998. Semantics in Generative Grammar. Oxford : Blackwell.

Heycock C. \& Kroch A., 1997. «Inversion and Equation in Copular Sentences ». ZAS Papers in Linguistics vol. 10, 71-87.

Heycock C. \& Kroch A.,1999. «Pseudocleft connectedness : Implications for the LF interface level ». Linguistic Inquiry, 30.3, 365-397.

Heycock C. \& Kroch A., 2002. « Topic, Focus, and Syntactic Representations ». In : Mikkelsen L. and Potts, C. (Eds.), WCCFL 21 Proceedings. Cascadilla Press, pp. 141-165.

Higgins, F. Roger, 1973. The Pseudo-Cleft Construction in English. Ph.D dissertation, MIT.

Higgins, F. Roger, 1979. The Pseudo-Cleft Construction in English. New York : Garland.

Kato, M. A., 2000. «The partial pro-drop nature and the restricted VS order in Brazilian Portuguese ». In : Kato \& Negrão (Eds.), Brazilian Portuguese and the Null Subject Parameter. Madrid \& Frankfurt am Main, Iberoamericana \& Vervuert, pp. 223-258.

Kayne R. S., 2002. « Pronouns and their antecedents ». In : Epstein S. D. \& Seely T. D. (Eds.), Derivation and explanation in the Minimalist Program. Malden, MA : Blackwell Publishing, pp. 133166. 
Kayne R. S. \& Pollock J.-Y., 2010. « Notes on French and English Demonstratives ». In Zwart J.-W. and de Vries M. (Eds.), Structure Preserved: Studies in Syntax for Jan Koster. John Benjamins, Amsterdam, pp. 215-228.

Kaiser G. A. \& Hack F. M., 2010. « Sujets et sujets nuls en romanche ». In : Iliescu M., SillerRunggaldier H. \& Danler P. (Eds), Actes du XXVe Congrès International de Linguistique et Philologie Romanes. Innsbruck 2007, Tome VII, Berlin : de Gruyter, 83-91.

Lasnik, H. and Uriagereka J., 1988. A Course in GB Syntax : Lectures on Binding and Empty Categorie s. Cambridge, Mass. : MIT Press.

Lee, C. 2002, « Contrastive topic and proposition structure ». In Sciullo, A.-M., Asymmetry in Grammar, John Benjamins. (Asymmetry Conference, UQAM, 2001) : 345-372.

Lefeuvre F., 1999. « Les marqueurs de prédication dans la phrase averbale en français ». Verbum XXI, 4, 429-438.

Macià J., 1996. « Binding Theory, Semantic Interpretation and Context». CatWPL 5/11, 81-112

Markman, V. G., 2008. « Pronomial Copula Constructions Are What ? Reduced Specificational Pseudo-Clefts ! » In Charles B. Chang and Hannah J. Haynie (Eds.), Proceedings of the 26th West Coast Conference on Formal Linguistics. Somerville, MA : Cascadilla Proceedings Project, pp. 366-374.

Mikkelsen, L., 2002. « Specification is not inverted predication ». In M. Hirotani (Ed.), Proceedings of NELS 32. Amherst, MA : GSLA, pp. 403-422.

Mikkelsen, L., 2004. Specifying Who: On the Structure, Meaning, and Use of Specificational Copular Clauses. Ph. D. thesis, University of California, Santa Cruz.

Mikkelsen Line, 2005, Subject Choice in Copular Clauses, ms.

Mikkelsen, Line., 2006, « On So-Called Truncated Clefts » [Pre-publication draft of April 9, 2006]

Mikkelsen Line, 2011. «Copular Clauses ». In : Maienborn C., von Heusinger K, and Portner P. (Eds.), Semantics : An International Handbook of Natural Language Meaning, volume 2. Berlin : Mouton de Gruyter, pp. 1805-1829.

Moltmann F., 2013, « Tropes, Bare Demonstratives, and Apparent Statements of Identity » Noûs 47.2., pp. 346-370.

Moro, A., 1997. The Raising of Predicates : Predicative Noun Phrases and the Theory of Clause Structure. Cambridge : Cambridge University Press.

O'Neill, T., 2012. « Demystifying Double-is ». University of Pennsylvania Working Papers in Linguistics Volume 21, Issue 1 Proceedings from PLC 38, article 23.

Partee, B. H., 1987. « Noun phrase interpretation and type-shifting principles ». In : J. Groenendijk, D. de Jongh, and M. Stokhof (Eds.), Studies in Discourse Representation Theory and the Theory of Generalized Quantifiers, vol. 8 of GRASS. Dordrecht : Foris Publications, pp. 115-144.

Partee B. H., 1998. « Copula Inversion Puzzles in English and Russian ». In : Dziwirek K., Coats H., and Vakareliyska C. (Eds.), Formal Approaches to Slavic Linguistics: The Seattle Meeting 1998. Ann Arbor, Michigan Slavic Publications, pp. 361-395.

Partee B. H., 2010. « Specificational copular sentences in Russian and English ». In : Grønn A. \& Marijanovic I. (Eds.), Russian in Contrast. Oslo Studies in Language 2(1), pp. 25-49.

Pereltsvaig A., 2001. On the Nature of the Intra-Clausal Relations : A study of Copular Sentences in Russian and Italian. Dissertation, McGill University Montréal. 
Pollock J.-Y., 1983. « Sur quelques propriétés des phrases copulatives en français ». Langue

Française, V. 58.1, 89 - 125.

Rapoport T., 1987. Copular, Nominal and Small Clauses. A Study of Israeli Hebrew. Dissertation, MIT.

Reinhart T., 1976. The Syntactic Domain of Anaphora. Doctoral dissertation, MIT.

Roy I. A., 2006. Non-Verbal Predications : A Syntactic Analysis of Predicational Copular Sentences. PhD Dissertation, University of Southern California.

Rutkowski P., 2006. «From demonstratives to copulas : a cross-linguistic perspective and the case of Polish». Journal of Universal Language 7.2, 147-175.

Rouveret A., 1998. « Points de vue sur le verbe "être" ». In Rouveret A. (Ed.), "Etre" et "Avoir" : syntaxe, sémantique, typology. Presses Universitaires de Vincennes, Saint-Denis, pp. 11-65.

Schlenker P., 2003. « Clausal Equations (A Note on the Connectivity Problem) ». Natural Language and Linguistic Theory 21, 157-214.

Uzun N. E., 2006. «A Hierarchical Explanation against the Distinction of Nominal Copular Sentences in Turkish ». Turkic Languages 10, 111-130.

Vinet M.-T., 1993. « L'aspect et la copule vide dans la grammaire des titres ». Langue française, vol. 100.1, 83 - 101

Grammaire de la Phrase Française, 1993, Le Goffic P., Hachette.

Grammaire du Français Classique et Moderne, 1991, Wagner R. L. et Pinchon J., Hachette.

Grammaire Méthodique du Français, 1993, Riegel M., Pellat J.-C. \& Rioul R., PUF.

\section{NOTES}

1. I am very grateful to Georges Rebuschi and Laurent Gosselin for reviewing this work and for their comments, which helped me so much. I also wish to thank the two Corela's anonymous reviewers. I tried my best to take into account their interesting comments.

2. C-command will be defined in the next section.

3. For example, $a=$ a would be « John is John » and $a=b$, « John is Mr Smith ».

4. An apparent counter-example could be the following:

(i) Dans Astérix : Mission Cléopâtre, Gérard Depardieu est Obélix.

In the movie "Astérix : Mission Cléopâtre", Gérard Depardieu is Obélix

Even though here Obélix can be seen as a referential expression, we agree with Rouveret (1998) and Rapoport (1987) that it has to be considered as a predicate in this movie-context, and thus it does not contravene Principle $C$. We will not consider this type of sentence here.

5. When the demonstrative is present, in Polish and Russian, the instrumental case is banned, while the instrumental case is good when the demonstrative is absent.

6. We retain here Citko's (2008) judgments.

7. There exists a form for be in the present tense, namely est', but it has a constraint behavior, cf. Geist (2008). It can appear in definitions, tautologies or with a contrastive intonation which gives rise to a particular reading which Geist calls "verum-Fokus", which corresponds to one of the case of accentuated est in French, cf. section 3.3.

8. Cf. also Partee $(1998,2010)$

9. A context for this sentence could be the following: we do not know that that Cicero and Tullius are de same person, and someone comes and say « Mais Cicéron EST Tullius ». 
10. One of the anonymous reviewers rejects this sentence, even with a strong stress. We agree that it is difficult to find a context where it could be uttered.

11. Notwithstanding other proposals which have been made, cf. Clech-Darbon \& al. (1998).

12. There are several assumptions on the way of deriving dislocation : by movement of a term from an argument position towards a non-argument position (with a visible trace or a copy pronoun), or by direct merging of the dislocated term and presence of the pronoun in the numeration (cf. De Cat, 2004), or the intermediary way (cf. Kayne, 2002): presence of a component formed by the referential term and the pronoun in the argument position and displacement of the referential expression alone towards an A-Bar position. Whichever hypothesis is adopted, the dislocated term A-Bar binds the pronoun in the argument position.

13. Moltmann (2013) also proposes that bare demonstratives this and that (presentational pronouns) in identification sentences do not refer to individuals. She makes the assumption that this and that denote perceptual features or tropes in such sentences.

14. Different approaches of the Small Clause have been proposed, the problem being the status given to it. In example (), the association of the proper noun Cunégonde and of the adjective forms a Small Clause, but what is the nature of this SC? Is this a projection of the adjective or something else?

15. Cf. Rouveret (1998: 43-44) where the author adopts a diametrically opposite view and, according to which, the Small Clause structure cannot account for the behaviour of $c$ ' in these sentences.

16. We give this example for the sake of our discussion, but we will not go into details of the analysis of XP c'est Adjective sentences in the terms of the present proposal. This analysis is possible but needs additional explanations.

17. In Old French, ce was the predicate while the post-verbal subject was nominative Case (je, tu, il ,...), (cf. Pollock, 1983), and we can observe that the verb agrees with the subject :

a. Ce suis je.

CE am I

b. Ce es tu.

CE are you

c. Ce est il.

$\mathrm{CE}$ is he

d. Ce sommes nous.

CE are we

e. Ce estes vous.

$\mathrm{CE}$ are you

f. Ce sont ils.

CE are they

Bouchard, Dupuis \& Dufresne $(2007: 4)$ explain that in the $12^{\text {th }}$ century, ce in subject position is possible, but $c e$ in predicate position still dominates. However, this tendency starts to change in the $13^{\text {th }}$ century. Thus, the form "ce est il" has slowly changed into "c'est lui", indeed both forms could be found until the $16^{\text {th }}$ century. This has given rise to a change of ce suis je into c'est moi, which appeared after c'est lui in the first place, but propagated quicker.

18. Cf. among others, Grammaire Méthodique du Français (Riegel, Pellat \& Rioul, 1993), Grammaire du Français Classique et Moderne (Wagner et Pinchon, 1991) and Grammaire de la Phrase Française ( Le Goffic, 1993).

19. Markman (2008) gives the following example :

*Misha schitajet [Dimu eto (doctor/ doctor-om)]

Misha considers [Dima eto doctor- nom/doctor-instr]

Misha considers Dima this doctor

Finally, Markman (2008) makes the assumption that the demonstrative is directly inserted as the 
Topic head. For Polish, Citko (2008) proposes that to is in the head of T while Baylin (2004) treats it as the head of PredP.

20. Different issues need to be addressed, among which :

(i) c' as a head incorporates the verbal head occupied by est, and the form c'est then moves from head to head : this leaves [Spec, IP] empty. A way of dealing with this problem could be that $c^{\prime}$ is nominative and, though as a head it cannot go into Spec, IP, but moves with est in $I^{\circ}$, it can satisfy the nominative requirement in this position and/or it can legitimate an expletive pro in [Spec, IP] thus satisfying EPP.

(ii) Where exactly is est? We have posited it in a $v^{\circ}$ projection, while some analyses put is as the head of TP.

(iii) What triggers movement of the Topic and that of Focus? Can we assume Topic and Focus features (cf. Mikkelsen, 2005) ? Or can these features be subsumed by other types of features, as + referential for the movement of Topic, and + Quantification for movement of Focus?

21. Amazingly, while Binding Principles have been avoided for copular sentences, the "reconstruction effects" phenomenon has benefited from much research, cf. Schlenker (2000), den Dikken (2006), Mikkelsen (2011) among many others. Schlenker (2000) gives the following examples :

(i) a. What John likes is himself.

b. John likes himself.

Here himself must satisfy Principle A, which is the case for (b) but not for (a) where John does not c-command himself. However sentence (a) is fine. We leave this point aside for French, as it would need a detailed study in itself. Let us just mention here that French does not follow the behavior of English, because, first, sentence (ia) would be bad in French (cf. iia), but even when it is augmented with the demonstrative, the validity of lui-même does not prove anything, for lui is also possible (cf.iib) :

(ii) a. ${ }^{*}$ Ce que Jean aime est lui-même.

What John likes is, himself

b. Ce que Jean aime c'est lui-même/lui.

What John likes CE is himself/him

This is clearly due to the particular behaviour of the pair lui/lui-même in French.

22. In Pollock (1983), it is the verb est which assigns a $\theta$-role to the subject $i$.

23. Saying that $i l$ has a virtual reference means that it has potentially a reference, but it needs to be actualised.

24. We give here the resulting trees, leaving a side the projections below IP (VP, PredP...).

25. This type of sentences is not standard English, but still it needs to be addressed.

26. Diessel (1999) analyzes the grammaticalization of demonstratives in a general way and in different languages, but he just mentions French demonstrative $c$ ' in clefts and treats it as an expletive. On the other hand, Rutkowski's (2006) work is based on Polish data and on the possible grammaticalization of to : he assumes that the process of grammaticalization of to as a copula has not yet been completed in Polish. It could also be the case that French $c^{\prime}$ (or c'est) is on its way to being grammaticalized, a process which is not yet finished.

27. It should be noted that Kayne \& Pollock (2010) arrive at the same result concerning c'est adjective sentences: for them, c'est adjective sentences are specificational. Also cf. AmaryCoudreau (2012) 


\section{RÉSUMÉS}

Dans la littérature, le Principe $C$ de la Théorie du Liage est considéré comme ne s'appliquant pas aux phrases copulatives, sur la base des données anglaises. Cependant, le présent travail montre que ce principe s'applique aux phrases copulatives françaises. Le français marque une distinction entre les phrases prédicationnelles et les autres types de phrases copulatives (identificationnelles, identité, spécificationnelles) : les premières présentent le verbe est tout seul, alors que les autres types de phrases nécessitent la présence du démonstratif neutre "ce/c"'. Nous montrons que, en français, les deux termes autour de la copule ne peuvent pas être coréférentiels, en accord avec le Principe $C$ du Liage. Ainsi, la présence du pronom "ce" modifie la structure sous-jascente de la phrase et aboutit en une structure de surface de type Topic c'est Focus, laquelle échappe au Principe C.

Although, in the literature, Principle $\mathrm{C}$ of Binding Theory is taken not to apply to copular sentences on the basis of English data alone, this study aims to show that this Principle applies to French copular sentences. French displays a dichotomy between predicational copular sentences and other subtypes of copular sentences (specificational, identity and identificational) : while the former use the verb est ('is') alone, the latter need an additional form, namely the neuter demonstrative pronoun ce. Evidence is given that, in French, the two terms flanking the copula est cannot be referential because the post-copula term would be bound by the pre-copula one, in accordance with Principle $\mathrm{C}$ of Binding Theory. Thus, adding the pronoun ce modifies the (deep) structure of the sentence and gives rise to a Topic c'est Focus (surface) structure, which escapes Principle C.

\section{INDEX}

Mots-clés : Liage ; Français ; copule ; spécification ; identification ; identité ; prédication ; pronom demonstratif.

Keywords : Binding ; French ; copula ; specification ; identification ; identity ; predication ; demonstrative pronoun.

\section{AUTEUR}

\section{VALÉRIE AMARY}

Laboratoire Crisco, Université de Caen, Normandie, valerie.amary@unicaen.fr 